
(1) 10 at if $=0$

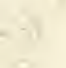
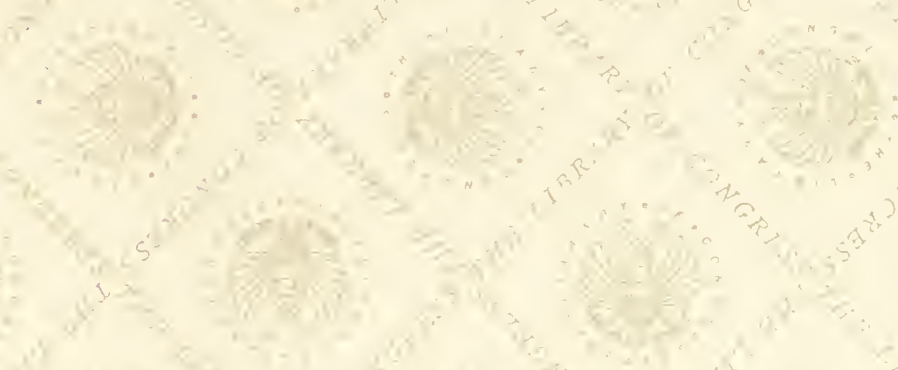

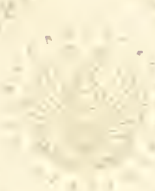

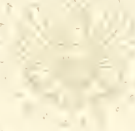

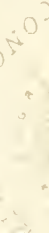

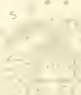

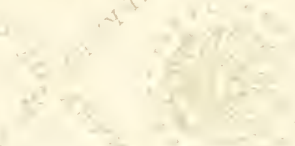

$\frac{81}{81}+$

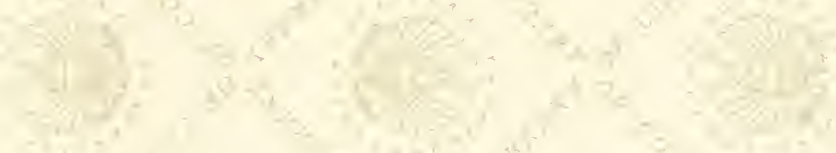

$\because x^{2}+4$

$\sqrt{20}+2$

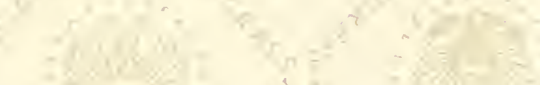

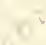

$y^{2}=$

$x^{4}=$

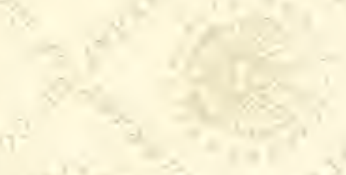

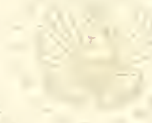

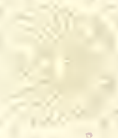

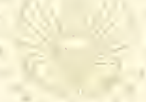

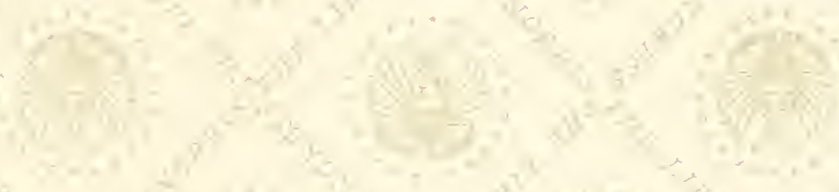

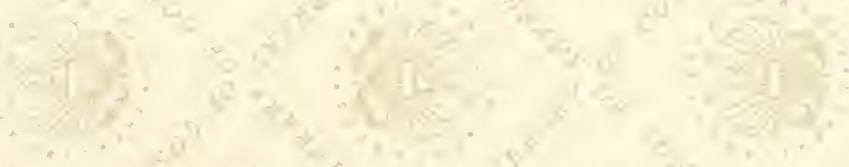

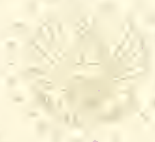

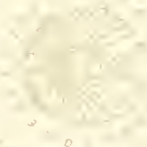

- in ,

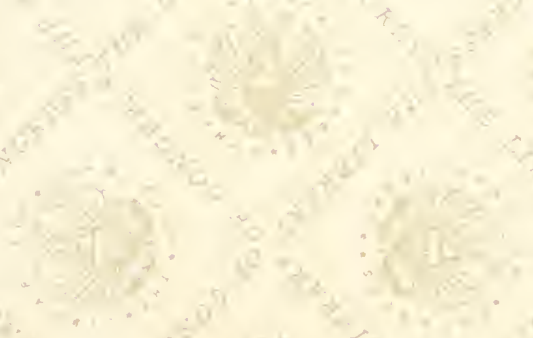







\title{
THE ZOOCECIDIA OF NORTHEASTERN UNITED STATES AND EASTERN CANADA
}

\author{
A DISSERTATION \\ SUBMUTTED TO THE FACULTY \\ OF THE OGDEN GRADUATE SCHOOL OF SCIENCE \\ IN CANDIDACY FOR THE DEGREE OF \\ DOCTOR OF PHILOSOPHY \\ DEPARTMENT OF BOTANY \\ BY \\ BERTRAM WHITTIER WELLS
}

Private Edition, Distributed By

THE UNIVERSITY OF CHICAGO LIBRARIES

CHICAGO, ILLINOIS

Reprinted from

The Botanical Gazette, Vol. LXV, No. 6

June, IgI 8 



\title{
Tbe antversity of Cbicago
}

\section{THE ZOOCECIDIA OF NORTHEASTERN UNITED STATES AND EASTERN CANADA}

\author{
A DISSERTATION \\ SUBMITTED TO THE FACULTY \\ OF THE OGDEN GRADUATE SCHOOL OF SCIENCE \\ IN CANDIDACY FOR THE DEGREE OF \\ DOCTOR OF PHILOSOPHY \\ DEP.ARTMENT OF BOTANY
}

BY

BERTRAM WHITTIER IIELLS

Private Edition, Distributed By

THE UNIVERSITY OF CHICAGO LIBRARIES

CHICAGO, ILLINOIS

Reprinted from

The Botanical Gazette, Vol. LXV, No. 6

June, 1918 



\section{THE ZOOCECIDIA OF NORTHEASTERN UNITED STATES AND EASTERN CANADA}

CONTRIBUTIONS FROM THE HULL BOTANICAL LABORATORY 239

B. W. WELLS

This summary is based upon a completed descriptive account ${ }^{\mathrm{I}}$ of the zoocecidia of the region studied, which is that phytogeographic region dealt with by GRAY's New Manual of Botany (7th ed., I908). The only similar general statement preceding this is that of FELT (4), who has presented some approximate figures from an entomological standpoint pertaining to American insect galls. The mite (Eriophyidae) galls were not included in his discussion.

\section{Historical}

Three local studies of zoocecidia have been made which deserve mention in a brief historical account. СоОK (2) in 1904 published the description of 66 galls from Indiana. JARvis (7) in I908 presented a catalogue of the insect galls of Ontario, comprising $22 \mathrm{I}$ species. Stebbins (Io) in 1910 described 205 species of galls collected in the vicinity of Springfield, Massachusetts. A posthumous catalogue of 233 southern New England galls by THompson (II) appeared in I9I5, edited by FeLt. This also included a. summary of American Cynipidae galls, listing 350 species.

For the sake of comparison a short summary of the European work will be given. HAimioffen (5) in 1858 presented 350 as the number of zoocecidia for central Europe. Schlechtendal (9) in I89 I listed I3I5 insect, mite, and nematode galls on the plants of Germany. KiefFer (8) in IgO I published a synopsis of the zoocecidia of Europe. There also appeared the same year a more exhaustive study in DARBOUX and HouARD's (3) systematic

I The work contains the description of 792 nematode, mite, and insect galls; half of this number will be supplemented by illustrations. Keys to the galls on the various plant genera have been made, the plant genus constituting the unit by which the galls have been grouped. 
catalogue of the zoocecidia of Europe and the basin of the Mediterranean, a work which in 1908 (supplement I9I3) was expanded by HoUARD (6) into the largest systematic cecidological work in existence. This final general European work comprises the description of 1950 zoocecidia.

\section{Basis and plan of work}

The data from which the following summary is drawn were obtained during a period of 4 years, in which field studies in Connecticut, Ohio, and Kansas were supplemented by a thorough canvass of the highly scattered cecidological literature.

It may be of interest to mention the simple and, it is believed, practical scheme which has been followed in the arrangement of the 792 types described. The plant genus was made the unit under which the galls were grouped. This is in contrast to HoundD's plan; he used the species, a plan which necessitated a vast amount of repetition, since innumerable galls occur on more than one species within the genus. It is a striking fact that very few galls are found upon more than one genus. In the study of the galls of the northeastern United States, data concerning the plant species bearing the gall have been included with the descriptive material. To assist in locating the descriptions, keys were worked out for the genera having more than 6 or 8 species. A brief bibliography presenting the most important references was appended to each description.

The plant genera in the work have been arranged alphabetically. The galls under each genus have been aggregated according to the classification of the cecidozoons. It is thus evident that artificial classification has been pursued throughout. At the present time any classification of zoocecidia must be artificial. The morphological data available, particularly of an anatomical nature, are far too meager to make possible anything approaching a natural classification.

\section{Summary of numerical data}

In the case of all of the following figures presented, it should be understood that they are but approximations. So new is the field of systematic zoocecidology in America, and so incomplete and 
unsatisfactory are the data in innumerable specific instances, that at the present time any generalizations of a numerical nature cannot be accepted as expressing the exact condition.

A tabulated statement of the 792 galls known from the northeastern quarter of the United States and eastern Canada, according to the cecidozoon orders and families, is as follows:

DISTRIBUTION BY ANIMAL FAMILIES

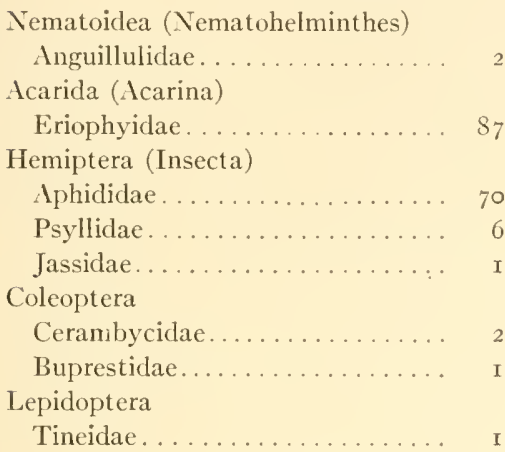

Gelechiidae.............. 3

Elachistidae............ 2

Sesiidae............... I

Tortricidae.............. 2

Unclassified................ Io

Diptera

Trypetidae.............. 7

Itonididae . . . . . . . . . . . . $3^{8} 3$

Hymenoptera

Chalcidae.............. 2

Tenthridinidae ............ I3

Cynipidae.............. I94

As FeLt has pointed out, the family containing the most gall makers is the Itonididae, embracing in our region 47 per cent of the gall biota. The Cynipidae follow with 37 per cent. The other families are represented by much smaller percentages, the Coleoptera being barely represented with 3 ill-defined galls.

The distribution of the galls (except nematode) by the plant families on whose members they occur is as follows. The families are arranged in the sequence given in Gray's Manual.

\section{DISTRIBUTION BY PLANT FAMILIES}

\begin{tabular}{|c|c|c|c|c|}
\hline Pinaceae........... & I 3 & Aristolochiaceae...... & 2 & Rosaceae.......... \\
\hline Typhaceae.......... & I & Polygonaceae......... & 2 & Leguminosae........ \\
\hline Gramineae.......... & 5 & Chenopodiaceae...... & 5 & Euphorbiaceae....... \\
\hline Cyperaceae........ & I & Nyctaginaceae...... & I & Inacardiaceae...... \\
\hline Juncaceae.......... & $\mathrm{I}$ & Portulacaceae....... & I & Aquifoliaceae....... \\
\hline Liliaceae. . . . . . . . . & 9 & Ranunculaceate...... & 7 & Celastraceae........ \\
\hline Iridaceae . . . . . . . . & I & Magnoliaceae. . . . . . & 2 & Aceraceae. . . . . . . . \\
\hline Salicaceae.......... & 60 & Lauraceae. . . . . . . . . & 5 & Balsaminaceae...... \\
\hline Juglandaceae . . . . . . & 64 & Papaveraceae....... & I & Rhamnaceae........ \\
\hline Betulaceae.......... & IS & Cruciferae........... & I & Vitaceae........... \\
\hline Fagaceae........... & $\mathrm{I} 8_{3}$ & Saxifragaceae........ & 5 & Tiliaceae........... \\
\hline Urticaceae.......... & 37 & Hamamelidaceae..... & 7 & Malvaceae.......... \\
\hline
\end{tabular}


DISTRIBUTION BY PLANT FAMILIES-Continued.

\begin{tabular}{|c|c|c|c|c|c|}
\hline Hypericaceae. . . . . . . & 2 & Ericaceae ... . . . . . . & I 7 & Labiatae. & I 4 \\
\hline Violaceae . . . . . . . & 2 & Primulaceae. . . . . . & I & Solanaceae .......... & 3 \\
\hline Cactaceae... & I & Ebenaceae... & 2 & Scrophulariaceae.... & \\
\hline Lythraceae......... & I & Oleaceae. . & 6 & Bignoniaceae....... & \\
\hline Onagraceae......... & I & Apocynaceae. . & I & Rubiaceae.... & \\
\hline Araliaceae.... & I & Asclep & 2 & Caprifoliaceae. & I6 \\
\hline Umbelliferae. . & I & Convolvulaceae..... & I & Compositae..... . & $\mathrm{I} 2 \mathrm{I}$ \\
\hline Cornaceae... & II & Verbenaceae........ & 3 & & \\
\hline
\end{tabular}

The striking fact brought out by this list is the extreme irregularity of the distribution. Many of the larger families have few or no galls, while on the other hand a few of the smaller families, particularly the Fagaceae, possess many cecidia. Quercus alone has 176 galls, of which 157 are cynipid types. FeLT presents 277 as the approximate figure for the cynipid galls on the American oaks. The Cynipidae-Quercus situation in Europe as well as in America presents the most striking example of gall evolution within a single genus of plants related to a comparatively few (9 or ro) closely related genera of insects.

It is worthy of note that such large families as the Caryophyllaceae, Cruciferae, and Boraginaceate contain no gall-bearing species. The Umbelliferae possess but a single gall. The widely distributed tree species Platanus occidentalis does not bear any zoocecidia.

The problem in distribution on the plants presented by the preceding list is an exceedingly difficult one and probably cannot be answered on the basis of the physiological information at present available. This intimate and constant relation between specific insects and specific plants forms one of the most significant phenomena in the field of cecidology.

As far as data were obtainable, figures were worked out indicating the distribution of the galls on the plant parts, with the following result:

\section{DISTRIBUTION ON PLANT P.ARTS}

On leaf blade (of these 52 are "blister" galls) ............... +27

On petiole (most of these occur also on blade).

On stem ( $S$ per cent of these occur also on the leaf)...

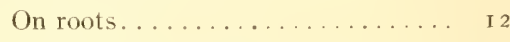

On flowers............... 27

From buds forming a rosette type... 47 From buds forming a solid concentric type................. 30 
Slightly over half of the galls (53 per cent) occur on the leaf blade. This fact is of course related to the relatively large amount of embryonic leaf tissue exposed in the early stages of shoot development. In the cases of the stem, root, and bud galls numerous factors enter, but perhaps the most important is the factor of insect equipment necessary to place the larval cecidozoon in contact with the meristematic tissues.

Some figures pertaining to gall structure were obtained which are of interest. A few words of explanation are necessary before presenting the tabulation. Under the monothalamous galls were included those types which, so far as could be determined, are generally one-chambered, that is, the gall never is a structure constantly characterized by the confluence of the walls of two or more chambers as in the polythalamous condition. A few species are intermediate and were classified in the direction in which it was believed they leaned the more strongly. A number of galls, such as the erineum (hypertrophied epidermal cells) types, do not fall in either of the above categories and cannot be included in such a classification.

In those cases in which sufficient data were available, an attempt was marle to study the galls on the basis of KüsTER's division of cecidia into kataplasmas and prosoplasmas. By "kataplasmas" KÜSTER means those indefinite, indeterminate galls whose structure is developed through hyperplasia of embryonic tissue, the end product not becoming in its differentiation, orientation, and form of tissues fundamentally different from the normal plant part. "Prosoplasmas," on the other hand, are highly definite and determinate galls whose structure differs fundamentally from the normal plant, the tissues in their form and orientation characters constituting an aggregation of new qualities. These two groups intergrade, but the intergrading forms are relatively few in number and were classified according to what was believed to be the predominating condition. In all cases where data were not sufficient to pass judgment, the gall was omitted from the census.

Another set of figures presented is that based on KüsTER's classification of galls into organoid and histoid types. An "organoid" gall is one in which an entire plant organ (leaf, stem, 
internode, ovulary, etc.) as a unit suffers modification without a fundamental change in its morphology. The "histoid" galls are those more numerous types in which an entire plant organ is not involved, the gall being more or less definitely appendicular. 'This group includes all of the prosoplasmas and part of the kataplasmas.

DATA BASED ON NUMBER OF CHAMBERS

Monothalamous galls 408

Polythalamous galls.

Non-chambered galls

Insufficient data to classify

183

The excessively large number of monothalamous forms is a fact related to the character of oviposition. If the eggs are habitually deposited in an aggregate manner, a polythalamous gall is almost certain to result, although there are striking exceptions to this. The great majority of larvae, however, begin their gall-making activity at sufficient distance apart to develop the common monothalamous types of cecidia.

KATAPLASMAS AND PROSOPLASMAS

Kataplasmas... 395

Prosoplasmas.

Insufficient data to classify

Viewed from an evolutionary standpoint, the kataplasmas represent the lower levels and the prosoplasmas the higher. That the latter have undergone a considerable expansion indicating relatively rapid progress in recent geologic time is evidenced by the relatively large number of prosoplasmas.

ORG.INOID AND HISTOID GALLS

Organoid 215

Histoid 495

Insufficient data to classify

82

These figures have no special significance, perhaps, other than the indication of differences in the range of the gall stimulus. In the organoid types the stimulus is diffused over relatively large areas, inciting all of the tissues of one organ to hypertrophy and hyperplasia. In the histoid forms the stimulus only affects those tissues in a restricted area about the cecidozoon, these tissues responding in a definite and striking manner. 
In addition to the above two tables KüstER has, in his classification of cecidia, furnished the basis for another table in his analysis of the prosoplasmas. 'These he divides into four groups: the leaf edge "roll" galls; the diverticulum or outpouching types; the "walled" (umwallungen) forms, whose walls grow up about the superficial larva; and the concentric (mark) cecidia whose larvae inaugurate gall formation from a point within the tissue. In the following list this classification was extended to include so far as possible the kataplasmas also, since a great many of these latter galls can properly be placed under some one of the preceding four groups. The $5^{8}$ "rosette" and the 28 erineum types cannot be included.

NUMBERS OF VARIOUS GALL TYPES

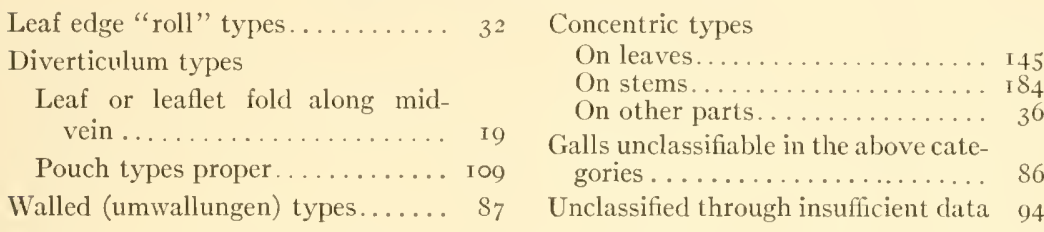

The factors entering into the production of these various kinds of galls are many; a full discussion of them cannot be presented here. Attention, however, should be called to the two main groups, namely, those which are related to the plant and those related to the cecidozoon. The diverticulum galls are, with few exceptions, only known from the leaf, particularly the blade, since this organ only is sufficiently free from stereome tissues to make possible the characteristic pouching out on the side opposite the cecidozoon. The walled and concentric types can occur on any part of the plant, the latter constituting a much larger aggregation than any of the other kinds. Oviposition within the plant tissue or a migration inward on the part of the larva is necessary for the production of the concentric type of gall. Even in these cases constituting the highest galls, plant factors can exert a modifying influence. The study of the relative importance of the two groups of factors entering into cecidium morphogenesis in specific cases is one of the most valuable and suggestive in the field of zoocecidology.

UNIVERSITY OF ARKANSAS

Fayettevifle, Ark. 


\section{LITER.ATURE CITED}

I. Connold, E. 'T., British vegetable galls. New York. 1902.

2. Cook, M. T., The insect galls of Indiana. 2qth Ann. Rept. Dept. Geol. and Natural Hist. Indiana. pp. Sor-867. I 904.

3. Darboux, and Houard, C., Catalog systematique des Zoocécidies de l'Europe at du Bassin méditerranée. Paris. roor.

4. Felt, E. P., American insect galls. Ottawa Nat. 30:37-39. r9 6.

5. Hammoffen, G. R., Beobachtungen über die Menge und das Vorkommen der Pflanzengallen und ihre spezielle Verteilung auf die verschiedenen Pflanzengattungen und Arten. Verhandl. Zool.-Bot. Gesell. 8:285. I858.

6. Houard, C., Les Zoocecidies des Plantes d'Europe et du Bassin de la Meditteranee. 2 vols. Paris. I909. Vol. 3, P'aris. I913.

7. JArvis, T. D., A catalog of the gall insects of Ontario. $39^{\text {th }}$ Ann. Rept. Ent. Soc. Ont. 70-98. igos.

8. Kieffer, J. J., Synopsis des Zoocecidies d'Europe. Ann. Soc. Entom. France. 70:233-384. I90I.

9. Schlechtendal, D. H. R. V., Gallbildungen (Zoocecidien) der deutschen Gefasspflanzen. Zwickau. ISgr.

ıo. Stebbins, F. A., Insect galls of Springfield, Mass., and vicinity. Bull. 2. Springfield Mus. igro.

I . Thompson, M. T., An illustrated catalog of American insect galls. Edited by E. P. Felt. Nassau, N. Y. I915. 





